\title{
IT innovation for the bottom of the pyramid
}

DOI:

10.1145/2380656.2380665

Link to publication record in Manchester Research Explorer

\section{Citation for published version (APA):}

Heeks, R. (2012). IT innovation for the bottom of the pyramid. Communications of the ACM, 55(12), 24-27. https://doi.org/10.1145/2380656.2380665

\section{Published in:}

Communications of the ACM

\section{Citing this paper}

Please note that where the full-text provided on Manchester Research Explorer is the Author Accepted Manuscript or Proof version this may differ from the final Published version. If citing, it is advised that you check and use the publisher's definitive version.

\section{General rights}

Copyright and moral rights for the publications made accessible in the Research Explorer are retained by the authors and/or other copyright owners and it is a condition of accessing publications that users recognise and abide by the legal requirements associated with these rights.

\section{Takedown policy}

If you believe that this document breaches copyright please refer to the University of Manchester's Takedown Procedures [http://man.ac.uk/04Y6Bo] or contact uml.scholarlycommunications@manchester.ac.uk providing relevant details, so we can investigate your claim.

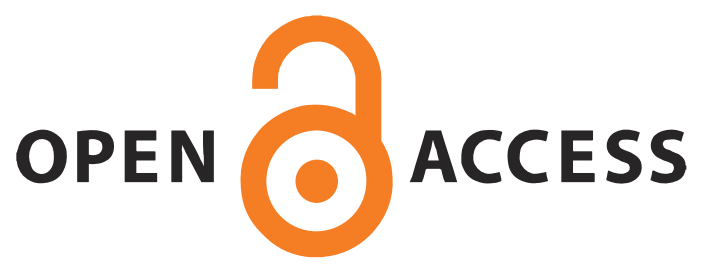


This is the pre-print version of the following article: Heeks, R. "IT innovation for the bottom of the pyramid", Communications of the ACM, 55(12), 24-27, 2012, which has been published in final form at:

http://dl.acm.org/citation.cfm?id=2380665

\section{IT Innovation for the Bottom of the Pyramid New ways to develop new technologies for the new growth markets}

The affluent markets of North America and Europe are tough places these days for IT. Competition is high, recession and uncertainty are never far away. It will be more logical for IT producers - big firms, small firms, universities, etc - to step outside their comfort zone, and focus on the mirror-image "bottom of the pyramid" (BoP). We can associate this generally with the emerging markets of low-income nations, or more specifically with that half of the planet's population who live on less than US $\$ 5$ per day. These markets are high-growth - e.g. mobile connectivity in Africa is growing by $30 \%$ per year and it is now the second-largest regional market after Asia ${ }^{1}$ - and they have lower competition. Overall, they represent the next frontier for IT.

But along with new markets must come new ideas about how we innovate IT. Traditional models of IT innovation vary. The mythology is the lone inventor soldering bits of kit together in their garage, or cranking out code in their attic. The reality is more often a well-funded R\&D team based around an IT lab in California or Massachusetts.

Though itself now splintering, this model has historically worked well in producing the new hardware and software to sell to high-income consumers. But it struggles - even fails - to produce the right products for the low-income consumers of Latin America, Africa and Asia. As examples, we can return, at best, an "open verdict" on the impact of transfer of the European-model "telecentre" and the US-developed "One Laptop Per Child" to the developing world. ${ }^{23}$

What is wrong with traditional models of IT innovation serving bottom of the pyramid markets? The simple answer is "design-reality gaps": too great a difference between design expectations built into the IT and the developing world realities in which the IT is to be used. ${ }^{4}$ And this typically arises because of the distance between innovators and users; not simply geographical distance but cultural, psychological, linguistic, etc.

In order to close those gaps, traditional approaches to IT innovation will no longer suffice. This article outlines six emerging IT innovation models that are helping to close design-reality gaps, and which are successfully delivering new products for low-income markets. They do not represent watertight categories - some of them overlap. But they do represent ideas we need to adopt if IT is to fulfil its potential for the huge emerging markets of the world's poor. Put more bluntly, if you don't adopt these models, someone else will. Indeed, someone else already is.

\section{Intermediated Innovation}

Large IT firms know their high-income markets well. But growth is happening elsewhere. How, then, to bridge that divide between what they know and what they need to know? One solution has been to engage with the new IT innovation intermediaries that have sprung up in recent years. They have a foot in both camps - a deep experience of how IT is used in low-income communities combined with an ability to understand the needs of big corporations. 
Bangalore in southern India has become a hub for these innovation intermediaries. Some are employed direct by multinationals: Microsoft Research (India) (http://research.microsoft.com/en-us/labs/india/) has developed relations with a set of poor communities through which innovations can be piloted; learning from such pilots can then be fed back to other parts of Microsoft. Others are guns for hire: the Centre for Knowledge Societies (http://cks.in/) is a contractor that works on behalf of large private firms; using a mix of anthropological and technological study methods within poor communities, it can report back to its clients with key IT innovation pointers.

Working via these new intermediaries, multinationals have been able to adapt their products, innovating to address the realities of bottom-of-the-pyramid environments. In this way, mobile phones have emerged with greater battery capacity or antenna strength, to cope with the lower coverage of mobile and electricity networks experienced by rural users. But the established IT firms have taken a broad-brush approach, using a single cheap model to serve markets across several continents. That has created an innovation gap which newlyarriving Chinese firms have been quick to exploit.

Already better-attuned to low-income customers than US and European rivals, they have created informal innovation channels to intermediaries like wholesalers and distributors. This has enabled them to adopt much smaller niche innovation strategies. In Kenya, for example, Chinese firms dominate cell phone sales to the poor, with a 90 percent market share in some areas according to recent University of Manchester research. Working with their intermediaries they have introduced innovations including dual sim card phones (allowing users to choose the lower-cost network to call particular contacts), translation of the phone interface into Swahili, and addition of a single-button-enabled new interface for the popular M-Pesa mobile money service.

\section{Collaborative Innovation}

In the intermediated innovation model, the intermediaries stand outside lowincome communities, and the poor are respondents more than they are participants in the innovation process. A step further down the road towards inclusivity of innovation is a collaborative approach with greater involvement of those who will ultimately be using the new IT.

This is mainly done through prototyping, and a well-known example is the M-Pesa service just mentioned which began facing in one direction and ended facing in quite another. Local Vodafone subsidiary Safaricom worked with Kenyan partners in piloting a cell phone application to help financial management in micro-finance institutions (organisations which manage micro-lending to the poor). The pilot did not work - the institutions disliked the new system and stuck with their existing manual methods.

But Safaricom designers noticed something unexpected: those provided with the service were converting cash into "m-cash" for security when travelling, and were then exchanging the $m$-cash to repay debts or help family members out. A lightbulb moment occurred, the project was re-oriented, and M-Pesa was born; as a service allowing users to transfer money from one cell phone to another. This was only possible because the firm's IT innovators worked alongside developing country users, and learned from them.

\section{Grassroots Innovation}

The previous example exposes a broader point - put IT tools into the hands of the poor, and they will themselves start to innovate. This is "grassroots innovation": not just innovation for the bottom-of-the-pyramid but innovation by 
the bottom-of-the-pyramid. Such innovations may be only minor but ethnographic study shows many IT-related appropriations and adaptations go on in poor communities:

- New processes e.g. beeping (or flashing) that allows a message to be communicated without the call being completed. Street vendors use this to receive free "I want to buy now" messages from known customers.

- New applications e.g. use of airtime as currency that allows cell phones to metamorphose into mobile wallets. Even before the advent of specialist mobile money services, those who own phones in poor communities have found ways to use them for payment (school fees, public transport, even kids' pocket money) or for receipt of remittances from distant relatives.

- New products e.g. back-street rechipping of phones. Informal-sector enterprises are emerging that strip and resell the circuitry from high-end phones, replacing it with basic calls-and-SMS-only functionality. They then sell the resulting high-end-body-with-low-end-organs as a unique hybrid for those who want the latest look but lack the budget to match.

Such innovations spread only haphazardly as yet. They are much like memes ideas that will mostly never see the light of day, but with a very few gaining momentum and being widely adopted. This is a huge pool of intellectual property: the IT equivalent of the great reserves of genetic biodiversity that lie within the tropical forests. And there will be similar moral questions about how these reserves are exploited.

Non-profit organisations like India's Honey Bee Network or the multi-country Prolinnova programme have been working for many years within poor communities to capture and share grassroots innovations; albeit with a focus todate on traditional rather than IT innovations. So inclusive models do exist. But large IT firms will increasingly recognise the value of grassroots innovations. They will then seek to formalise their currently somewhat jury-rigged connections with BoP markets, and will harvest, filter and diffuse such innovations on an industrial scale.

\section{Frugal Innovation}

An inherent characteristic of grassroots innovation - but also applicable to other models described here - is that it is "frugal". Frugality can be seen as a characteristic of the output - an IT product or application that is not just low-cost but also low-demand in terms of other resource requirements: electricity, telecommunications infrastructure, human skills, etc.

Multinationals can produce such items. The Nokia 1100 - the world's best selling phone - was a classic example of closing the gap between IT design and resource-constrained BoP reality. Robust in build, it was cut-down to the basic features that low-income consumers could pay for, and included a much-valued component: a flashlight. Specific initiatives like Copenhagen-based "Frugal Digital" (http://ciid.dk/frugaldigital/) are also working in this space, developing a low-cost health screening meter designed like a standard alarm clock, a mobile device to test hearing loss, and a basic educational projector.

But output is only one aspect of frugality - it can also be a characteristic of the innovation process; when new IT is produced far from a high-tech, high-cost laboratory but in a cut-price setting that is or imitates the context of its future use. Grassroots innovations are examples - frugal in both process and output but hard to capture. Of more immediate interest may be the frugal microinnovations of developing country inventors who focus on local communities. 
The World Bank's infoDev project (http://www.infodev.org) has been a keen supporter of frugal micro-innovators, providing finance, incubator spaces and training programmes to help them bring their ideas to market. An example is $M$ Farm (http://mfarm.co.ke): a simple SMS-based app which allows farmers to buy and sell direct, cutting out the middlemen who often rip them off.

\section{Innofusion}

Though they may get to grips with designing IT for use by poor consumers, many of the examples given above hold too narrow a view of what innovation is, equating it with invention, with the initial process of creating something new. But that is not enough to make an innovation effective - you have to move beyond the "build it and they will come" mentality, and recognise the importance of diffusion and adoption of the new IT.

This is particularly so in the case of BoP markets. Distribution is not about negotiations with supermarket or retail chains: they don't reach low-income consumers in the global South. Those consumers operate in conditions of poor infrastructure and services, and are reached by individual, locally-embedded micro-retailers and entrepreneurs.

But they too are innovators: the diffusion of a new IT product itself requires further innovations, so diffusion and innovation are bound together in a process we should call "innofusion". What's needed are incremental alterations to the way the technology is configured, packaged, marketed, sold, used, supported, serviced, etc. And those alterations are context-specific; attuned to the specific needs and expectations of each community. This isn't mass production, it is mass customisation. And it is rarely innovation of the core technology; more often innovation of the social processes that are essential to IT diffusion and use.

\section{Reverse Innovation}

Some of these innofusion innovations make their way upstream in the value chain, and represent a small example of our final model: reverse innovation. Reverse innovation represents the mirror image of traditional concepts of innovation. Those traditional concepts see a flow of objects and ideas from the producer to the consumer; from the rich global North to the poor global South. Reverse innovation sees the opposite.

In 2012, development informatics researchers were amused to see British bank advertisements.extolling the benefits of new services - such as PingIt - which would allow cell-phone-to-cell-phone transfer of money. In the UK, we are used to measuring our technological lag to the US: the time it takes for innovations to make it across the Atlantic. Now it seems the Mediterranean is the new crossing point: Kenyans, for example, have had mobile money transfer services since 2007. Thanks to the new innovation models, Africa is five years ahead of Europe, and the idea of m-money has flowed from poor countries to rich countries.

More prosaically, Cisco's ASR901 routers were developed for the needs of service providers in emerging Asian markets, but then backflowed to US and European clients. Their low-cost and energy-efficient designs arose from developing country realities, but offered a competitive advantage also in more mature markets.

\section{Summary}

Innovation is a term so overused it can start to lose its meaning. But serving the world's emerging markets - and perhaps lifting millions out of poverty at the same time - will require us to "do new things in new ways": the essence of 
innovation. More than that, it will require us to do innovation in new ways if we are to develop the new hardware and applications to achieve those goals.

For that to happen, we need a new mindset. One that sees the world's poor not in terms of the remote, helpless images used by development charities, but through more positive and active images which understand them at least as IT consumers and perhaps, further, as agents in their own development.

For IT multinationals, universities, innovators, etc in North America and Europe, this change in mindset may be particularly difficult given legacy attitudes towards the "Third World". There are already signs that IT firms in China and India are more adept at working with innovation intermediaries and at frugal innovation. Absent more change in the global North, it may be these mid-income nations which capture the next technological frontier that the bottom of the pyramid represents.

\section{References}

1. GSMA. African Mobile Observatory, GSMA, London, 2011.

2. Best, M. and Kumar, R. Sustainability failures of rural telecentres. Information Technologies and International Development, 4 (2008), 31-45.

3. Severin, E. et al. Evaluation of the "Una Laptop Por Niño" Program in Peru, IADB, Washington, DC, 2011.

4. Heeks, R. Information systems and developing countries. The Information Society, 18 (2002), 101-112.

Richard Heeks (richard.heeks@manchester.ac.uk) is Director of the Centre for Development Informatics at the University of Manchester, U.K.; http://www.cdi.manchester.ac.uk/ 